\title{
Problematizando uma Estratégia Multimetodológica de Pesquisa em Teatro e Educação ${ }^{1}$
}

\author{
Problematizing A multimethodological \\ Research's Strategy In Theater And \\ Education
}

Taís Ferreira*

\begin{abstract}
RESUMO
Neste artigo, que se caracteriza como um recorte de minha dissertação de mestrado, reflito acerca das escolhas metodológicas que compuseram o estudo empírico de recepção que propus junto a um grupo de crianças espectadoras de teatro infantil. Subdivido a escrita em quatro seções que contemplem alguns dos procedimentos metodológicos implicados na construção da estratégia multimetodológica traçada. Na primeira, discorro sobre a inspiração de cunho etnográfico que baliza alguns fazeres em campo junto às crianças e também os olhares constituídos por mim junto a elas. Também descrevo os sujeitos e contextos envolvidos na pesquisa de campo. Na seguinte, falo do lugar que considero como meu, enquanto professoratriz de teatro: do uso dos jogos teatrais como metodologia que possibilitaria, a partir de uma linguagem que não a oral, e sim a gestual e cisnestésica, a invenção de dados e materialidade empírica profícuos à pesquisadora $\mathrm{e}$ ao tema-objeto centrado no teatral. A proposta de coletar desenhos e registros gráficos das crianças, considerados forma de expressão construtora de significados e sentidos, é problematizada na terceira seção. Na última parte, dedico-me a refletir acerca das implicações das entrevistas e do formato escolhido para realizá-las junto às crianças espectadoras, das relações de força que atravessaram nosso estar junto, do narrar-se e rememorar enquanto mecanismos e técnicas de si, que constituem as posições ocupadas pelos sujeitos.
\end{abstract}

Palavras-chave: metodologias - teatro - educação - pesquisa empírica.

${ }^{1}$ Este texto é fruto das reflexões e discussões que tenho realizado como mestranda do PPGEdu/UFRGS, na linha Estudos Culturais em Educação, sob orientação da Professora Dra. Elisabete Maria Garbin, na qual tenho pesquisado acerca das experiências das crianças espectadoras com o teatro infantil.

*Bacharel em Artes Cênicas pela UFRGS. E-mail: taisferreirars@yahoo.com.br

Olhar de professor, Ponta Grossa, 7(1): 43-66, 2004. 


\begin{abstract}
In this article, which is part from my master degree dissertation, I reflect on the methodological choices that formed the empiric study reception that I proposed along a group of children expectators of childish theater. I subdivide this writing in four sections that point to some methodological procedures linked to the construction of the multimethodological strategy traced. Firstly I explain about the inspiration of ethnographic perspective, which mark some doings in field along children and also the observations constituted by me on them. I also describe the subjects and the contexts involved in the field research. Secondly, I expose the place I consider mine, as theater's 'acting teacher': the use of the theater's plays as methodology that would enable by a non oral but a gesture and kinesthetically language, the invention of data and empiric materiality concerning to the researcher and to the subject-theme centered in the theatric way. The proposal of collecting drawings children's graphic registration, considered as a form of expression of composed of meanings and senses, is problematized on third section. The last part, I present the reflections about the implications of the interviews and the chosen format to accomplish them close the children spectators, the power relations those marked our being together, of narrating and remembrancing while strategies and techniques of itself, those constitute subjects' positions.
\end{abstract}

Word key: methodologies - theater - education - empiric research.

A um ponto - não determinável dos percursos que percorri e percorro, quis compreender a(s) experiência(s) que envolviam o teatro, seus fazeres, suas possibilidades estéticas e sensíveis e as crianças. No entendimento da total impossibilidade da compreensão e de qualquer modo absoluto ou essencial de apreender o(s) infantil(is) em sua relação com o teatro, propus-me a estar junto. Olhar junto com o público infantil. Até agora tinha estado junto com crianças em várias posições de sujeito que ocupei e ocupo em relação ao teatral: a atriz jogando, a espectadora assídua e crítica que me constituí através das experiências com e no teatro e em outras instâncias, a professoratriz que garimpa nos e com seus alunos o teatral, a estudante a quem move a vontade de saber...

Obstáculos: permeada e constituída que estou /sou pelos discursos e práticas que de mim fizeram o outro, assumo a intransponibilidade entre elas - crianças - e eu - adulta, o que não me faz desistir e sim valorizar os instantes em que não olho para as crianças, nem sobre seus olhares, mas junto delas. Movimento de assalto, no qual a busca pela outridade assume o caráter de sua impossibilidade inerente, desejando correr os riscos da proximidade, surpreender-me com o banal, ver de outros modos o já visto tantas vezes: crianças em relação com o teatro. 
$\mathrm{Na}$ tentativa de contemplar as vontades (por vezes pretensiosas) de pesquisa que me mobilizavam e mobilizam, arrisquei-me a traçar algo que denomino aqui como uma estratégia multimetodológica de construção de dados. Sarmento (2003) reflete sobre a questão da coleta de dados e da "invenção dos dados" pelo pesquisador que se vale de metodologias de pesquisa qualitativa de cunho etnográfico de uma forma muito esclarecedora:

A recolha desse material lingüistico (dados) é quase sempre realizada num contexto comunicativo, no qual o investigador conversa, pergunta, entrevista, realiza a interação verbal que lhe permite apreender e interrogar os múltiplos sentidos que se cruzam nas escolas. Deste modo, o investigador etnográfico não 'colhe dados', como por vezes a urgência da frase-feita convida a dizer ou escrever. O investigador produz muitos dos seus materiais - as palavras das entrevistas, por exemplo - na interação social com os atores do terreno: 'Eles não são dados, mas criados'. De modo semelhante, as situações observadas são textualizadas sob a forma de notas de campo: mais próprio então chamar estes (não) dados de 'cenas' do 'teatro da vida'. (SARMENTO, 2003, p. 167). [grifos, aspas e parênteses do autor].

É dessa mesma forma que encaro os textos (verbais, escritos, visuais, corporais, cinestésicos) que criamos e construímos, as crianças espectadoras e eu, durante o estar junto do trabalho de pesquisa.

Há de se pensar, também, as implicações que determinados caminhos que compuseram o traçado da mencionada estratégia multimetodológica acarretaram, pois as escolhas e sua feitura nelas mesmas encerram potencialidades que poderiam, ou não, vir a ser "ou isto ou aquilo"; ou, ainda, nem isto nem aquilo... Portanto, problematizo as escolhas que o compuseram (o caminho e seu traçado) e a conseqüente construção da materialidade de meu percurso pesquisa. Trago a expressão estratégia multimetodológica por julgar que me valho de diferentes procedimentos e instrumentos metodológicos, provenientes de diferentes campos e áreas do saber, para compor uma estratégia que tem a finalidade de construir materialidades e sensações para as quais voltar-se-ão os olhares da pesquisadora.

Assim, dou seqüência à escrita subdividindo-a em quatro seções que contemplam alguns dos procedimentos metodológicos implicados na construção da estratégia traçada. $\mathrm{Na}$ primeira, discorro acerca da inspiração de cunho etnográfico que baliza alguns fazeres em campo junto às crianças e também os olhares constituídos por mim junto a elas. Na seguinte, falo do lugar que considero como meu, enquanto professoratriz de tea- 
tro: do uso dos jogos teatrais como metodologia que possibilitaria, a partir de uma linguagem que não a oral, e sim a gestual e cisnestésica, a invenção de dados e materialidade empírica profícuos à pesquisadora e ao temaobjeto centrado no teatral. A proposta de coletar desenhos e registros gráficos das crianças, considerados forma de expressão ${ }^{2}$ legítima e construtora de significados e sentidos, é problematizada na terceira seção. $\mathrm{Na}$ última parte, dedico-me a refletir sobre as implicações das entrevistas e do formato escolhido para realizá-las junto às crianças espectadoras, das relações de força que atravessaram nosso estar junto, do narrar-se e rememorar enquanto mecanismos e técnicas de si, que constituem as posições ocupadas pelos sujeitos.

Entretanto, antes de iniciar essas problematizações mais pontuais e referentes à prática junto às crianças sujeitos e personagens desta história, gostaria de levantar um aspecto que me parece ser de grande importância ao entendimento que tenho do trabalho e de como constituímo-nos, as crianças e eu, no momento mesmo de nosso estar juntos.

Quando jogávamos, conversávamos e desenhávamos sobre teatro, narrando nossas experiências, nossos quereres, gostares e desgostares, estávamos também nos constituindo em relação ao teatro, tema central de nossos debates e embates no curto espaço-tempo em que estivemos juntos. Lembrando Larrosa (1995), ao referirse ao pensamento de Foucault em seu estudo, posso inferir que as práticas que realizamos - com base nessa estratégia multimetodológica de construção de dados - podem ser consideradas "tecnologias do eu". Através delas as crianças constituíram-se, no momento mesmo em que as realizávamos, enquanto sujeitos espectadores de teatro. Ao brincar, contar, desenhar, perguntar, jogar, responder e criar, inventavam-se e percebiam-se também como os espectadores que estão a ser, que (des)constroem-se a cada dia de suas vidas, nas mais diferentes instâncias e em relação a artefatos de naturezas diversas.

Através das atividades que

\footnotetext{
2 Em relação ao controverso termo expressão, principalmente no campo da arte-educação, posiciono-me junto ao caráter que Larrosa confere ao conceito e sua operatividade, quando nos diz que "Seria possível, pois, considerar a estrutura geral do expressar-se como a dobradura reflexiva, sobre si próprio, dos procedimentos discursivos que constituem os dispositivos de construção e mediação da experiência de si. ( . . . ) O que ocorre, antes, é que, ao aprender o discurso legítimo e suas regras em cada um dos casos, ao aprender a gramática para auto-expressão, constitui-se ao mesmo tempo o sujeito que fala e sua experiência de si. Não se trata que a experiência de si seja expressada pelo meio da linguagem, mas, antes, de que o discurso mesmo é um operador que constitui ou modifica tanto o sujeito quanto o objeto da enunciação, neste caso o que conta como experiência de si." (LARROSA, 1995, p. 67-8).
} 
vivenciamos juntos, criamo-nos: eu pesquisadora, professoratriz; as crianças assumindo posições de sujeitos espectadores. Constituímo-nos, através dos citados "mecanismos de produção da experiência de si”, sujeitos junto à linguagem teatral, em relação (com) a ela. "A criança produz textos. Mas, ao mesmo tempo, os textos produzem a criança" (LARROSA, 1995, p. 46). E suas identidades e subjetividades como espectadores produzem-se concomitantemente à produção dos gestos, sons, falas, riscos e rabiscos, movimentos decorrentes das práticas que brincamos juntos.

\section{OBSERVANDO E (RE)CON- TANDO - OLHARES ETNOGRÁ- FICOS PÓS-MODERNOS}

Dia 1, Bento Gonçalves, 17 de setembro de 2003

Após um mês, encontrávamos novamente. Iniciamos as atividades com uma conversa, em que fiz perguntas e também fui questionada, na qual trocamos experiências e vivências, narrando uns aos outros nossas histórias e inventando a nós mesmos. Ao perguntar se sabiam porque estávamos ali, as respostas foram variadas: para brincar, para 'matar aula', para fazer entrevista, para jogar jogos, para fazer teatro. Muitas vezes, durante os cinco dias de atividades, ouvi de várias crianças que estávamos ali 'matando aula', ou seja, este espaço era um outro espaço que não a aula cotidiana e todos os dispositivos de disciplinamento e regulação que a constituem. Mesmo que estivéssemos dentro da escola, vigiados e observados, e que tenhamos desenvolvido nestes poucos dias mecanismos próprios de disciplinamento e regulação (diferentes dos da sala de aula), as atividades que realizávamos neste espaço-tempo eram lúdicas, não evocavam conteúdos trabalhados pelas professoras nas salas de aula. Enfim, para as crianças, o que fazíamos ali, ocupando um tempo em que deveriam estar debruçados em suas classes, definitivamente, não era aula. Por isso, 'matávamos aula'. Propus os jogos previstos no plano de ação, que foram acolhidos pela grande maioria das crianças sem resistência alguma e até com bastante entusiasmo. Os dois meninos da quarta série mostraram-se um pouco menos dispostos que os outros colegas. Sempre realizei os jogos em dois grupos, em que um faria e outro estaria observando, na posição de platéia. Em determinado momento, em que as crianças todas falavam ao mesmo tempo, gritavame agitavam-se, a Coordenadora do turno, que por ali passava, interveio. Sentou-se em uma cadeira e ficou observando-os com um olhar repressor. Todos se mostraram temerosos e, no mesmo ins-

Olhar de professor, Ponta Grossa, 7(1): 43-66, 2004. 
tante, pararam de rir, falar, etc. A disciplina mantida pela escola parece-me bastante rígida. Apesar de serem agitados (solicitei colaboração e silêncio diversas vezes), são extremamente disciplinados e acostumados a respeitar a 'autoridade'. As crianças são muito participativas, disponiveis e empolgadas. $O$ único momento em que ficaram caladas e paradas foi quando propus que preenchessem suas fichas, durante o último jogo. Parece-me que se divertiram com as atividades realizadas. O último jogo proposto (jogo das fichas com mímese) foi muito revelador dos significados primeiros atribuídos pelas crianças ao teatro, suas manifestações e linguagem.

Empolgada pelas possibilidades, pelos prazeres e anseios que de minhas escolhas poderiam ser frutos, aventurei-me por processos não vinculados estritamente a uma metodologia específica de pesquisa, permiti-me apropriar-me de práticas e métodos que me pareciam, naquele momento, os que melhor serviriam às minhas vontades de pesquisa. Assim sendo, busquei inspiração nas etnografias pós-modernas, que permitem ao pesquisador estar junto de seu objeto de pesquisa, de certa forma confundindo-se com ele, dissolvendo a dicotomia "sujeito-objeto", borrando as fronteiras (ainda que estas continuem a existir aliadas à alteridade do humano). Busco, neste trabalho, "inspirar-me livremente nas etnografias pós-modernas", em alguns escritos de Gottshalk (1998), Clifford (1995) e Geertz (1989), importantes nomes que respondem pelo que poder-se-ia chamar de "traços etnográficos pós-modernos" no campo da Antropologia. Entretanto, as metodologias etnográficas ultrapassam as barreiras do campo que assume sua paternidade para compor estudos nos campos da Psicologia, da Arte, da Educação, da Medicina, da Comunicação, entre tantos outros.

Fundamentada nesses autores, entendo que as etnografias pós-modernas distanciam-se das etnografias clássicas, ainda que tenham surgido baseadas em vários de seus preceitos e princípios metodológicos de pesquisa, principalmente aqueles concernentes aos trabalhos de campo. Todavia, nos estudos etnográficos clássicos, a observação prolongada e uma pressuposta neutralidade do antropólogo/ pesquisador ao narrar as "experiências do outro" lhe conferem um caráter essencialista que, posteriormente, será contestado e rearticulado nos chamados estudos etnográficos pósmodernos. Estes, por sua vez, permitem ao pesquisador trabalhar com diversas metodologias de pesquisa qualitativa articuladas, tais como a observação (participante ou não), a entrevista em profundidade, o relato autobiográfico, a análise de dados e materiais textuais. Outro pressuposto das etnografias pós-modernas é 
distanciar-se de uma suposta neutralidade do pesquisador, que passa a colocar-se também enquanto sujeito de pesquisa, na medida em que interfere nas próprias relações que está estudando; sua voz faz-se ouvir no texto etnográfico, contudo, não é mais a única como nas etnografias clássicas, em que o etnógrafo é unívoco e possui a autoridade para falar pelos sujeitos. Dessa forma, não há mais um olhar universal e transcendental, mas um olhar pessoal, em que o etnógrafo assume a especificidade de sua autoria e "do lugar de onde fala", abrindo espaço para que também as vozes dos sujeitos se façam presentes nas narrativas e estudos etnográficos pósmodernos, além das outras vozes sociais que atuam como mediadoras das vozes dos sujeitos e do pesquisador: a mídia, os contextos políticos e econômicos, os artefatos e as práticas culturais, os discursos, as linguagens, entre outras.

Tendo em vista o exposto, situome enquanto pesquisadora, no espaço (mal)dito da tradução. Da dívida permanente que a tradução nos impõe para com o outro, já que da sua impossibilidade absoluta nos constituímos: a linguagem como a impossibilidade permanente da tradução (DERRIDA, 2002), que, mesmo impossível, faz-se e vem a ser, constituindo-nos em seu fazer-se, na relação com o outro. Coloca Clifford que "a observação participante obriga a seus participantes a experimentar, em um nível tanto experimental quanto cor- poral, as vicissitudes da tradução" (CLIFFORD, 1995, p. 41).

Dessa forma, interpenetram-se a experiência e a interpretação como qualidades constituintes do etnógrafo. Mais tarde, unindo-se a elas, a reflexividade. Há, nas atividades de observação participante do etnógrafo, uma oscilação contínua entre "o dentro" e "o fora", "uma dialética entre a experiência e a interpretação" (id ibid, p. 53). Além dos modos ditos "experiencial" e "interpretativo" da "autoridade etnográfica", dos quais nos fala Clifford (1995), podemos encontrar também as autoridades "dialógica" e "polifônica", metáforas lingüísticas ou paradigmas discursivos que vão ao encontro do que anteriormente foi tratado: a presença de vozes que não só a do etnógrafo enquanto autoridade absoluta da "escritura etnográfica". Entretanto, não se apregoa a essencialidade de cada um desses paradigmas, sendo o próprio Clifford quem expõe esta potencial hibridação: "os modos de autoridade [...] - experiencial, interpretativo, dialógico e polifônico - estão disponíveis a todos os escritores de textos etnográficos [...]. Nenhum está obsoleto, nenhum é puro; há espaço para a invenção dentro de cada paradigma" (id ibid, p. 74).

Dando continuidade às reflexões que teço, inspirada pelos referencias das etnografias pós-modernas, apresento na seção seguinte as crianças espectadoras, sujeitos desta pesqui- 
sa, personagens da história que aqui (re)conto, e os contextos em que esta aconteceu e se construiu.

\section{OS SUJEITOS E O CONTEXTO}

“De que sujeito falar?", esta é a pergunta que dá título a uma das seções de artigo de Fischer (1995) e que também norteou uma importante escolha na prática que envolve este trabalho: de que infância falar, tendo em vista a multiplicidade e a volatilidade assumidas pelo infantil na pósmodernidade? Na completa impossibilidade de tentar demonstrar a relação das crianças com o teatro para elas realizado abrangendo uma grande variabilidade de "situações/ construções de infância”, optei por trabalhar em um contexto específico de recepção: a escola.

Tendo em vista as complexas relações travadas entre a instituição escolar, seus dispositivos de disciplinamento, regulação e normali-

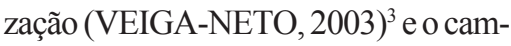
po do teatro infantil, e também o fato de ser esse o único contexto em que grande parte das crianças de classes desfavorecidas, da periferia de grandes centros urbanos e dos municípios do interior tem acesso à produção teatral considerada "profissional", julguei que seria profícuo limitar-me, neste momento investigativo, a esse contexto de recepção determinado, explorando suas especificidades e particularidades.

A escola, como já salientei anteriormente, apresenta-se como a "comunidade de apropriação" privilegiada do teatro pelas crianças. Os processos de recepção, que antecedem e extrapolam o momento do contato com os artefatos, passam por diversos cenários em seu movimento de construção de sentidos e significados. De acordo com Orozco, que é quem levanta os conceitos de "comunidade de apropriação" e de "comunidade de interpretação": "Em cada cenário se está negociando a mensagem e talvez produzindo novos significados ou confirmando os anteriores. Os cenários são todos aqueles lugares onde se produz sentido àquilo que se obtém dos meios de comunicação" (OROZCO GÓMEZ, 2000, p. 118).

Esse mesmo autor diferencia os termos comunidade de apropriação e comunidade de interpretação, referindo-se ao primeiro como os espaços, grupos ou lugares nos quais acontece a recepção em si. Podemos exemplificar dizendo que, no caso do público infantil, a família é a principal comunidade de apropriação da televisão, enquanto que a escola é a principal comunidade de apropriação do teatro.

Assim sendo, nos discursos e práticas (indissociáveis) das crianças espectadoras, busca pistas e intertextos que me conduzam a inves-

${ }^{3}$ Anotações feitas em palestra proferida pelo Prof. Dr. Alfredo Veiga-Neto junto ao PPGEdu/ UFRGS, em 2003/01. 
tigar, além da relação da construção das crianças enquanto espectadoras, qual a contribuição dos discursos e práticas escolares como mediadores desses complexos processos de recepção e da formação das identidades desses sujeitos enquanto espectadores híbridos.

Portanto, essa escolha orientavame a realizar meu plano de ação com crianças que assistissem a espetáculo teatral infantil através de suas escolas, ou em um edifício teatral, ou nas próprias dependências da instituição escolar.

Assim, nesta pequena narrativa, os cenários são a escola (pátio, refeitório, sala dos professores, sala debaixo da sala dos professores), a rua e o salão de um Centro de Tradições Gaúchas. O tempo é setembro de 2003, ensolarado, quase primavera, quase calor. O local é Bento Gonçalves, cidade da região Nordeste do estado do Rio Grande do Sul, com mais ou menos 100.000 habitantes, segundo o último senso do IBGE, fundada pela colonização italiana, industrializada, com amplas redes de ensino público e privado, em que todas as crianças em idade escolar freqüentam a escola.

Cheguei até essa instituição de ensino através de contatos travados com um grupo teatral da cidade que faria apresentação de um espetáculo teatral infantil para os alunos da escola, no mês de setembro de 2003 . Dessa forma, contatei a escola a fim de solicitar permissão para realizar o trabalho com as crianças em suas de- pendências e horários de aula, em acompanhar a ida delas da escola até o teatro, etc.

A Escola Estadual de Ensino Fundamental Irmão Egídio Fabris, localiza-se em um bairro de classe média, próximo ao centro da cidade e tem turmas da Educação Infantil e do Ensino Fundamental: Jardim B à quarta-série no turno da tarde, 9 turmas, em um total de 109 alunos; quinta a oitava séries no turno da manhã, além de uma turma de Jardim A, perfazendo um total de 210 alunos. Ao todo, são 391 alunos regulares freqüentando a instituição no ano letivo de 2003.

As primeiras impressões sobre o ambiente, registradas em meu Diário de Trabalho, são as seguintes:

A escola é pequena, limpa, organizada, paredes bem pintadas (de bege claro e escuro). Tem uma quadra ao ar livre e uma 'área coberta'. Uma biblioteca e uma parte nova, onde fica a 'sala dos professores'. As salas são dispostas ao redor da área coberta, tendo no centro a 'sala da direção'. No horário em que estive lá, não havia crianças no pátio, nem circulando pelos corredores. Aparentemente, todos estavam em suas salas de aula. Ordem e limpeza. Lembra-me um pouco a época em que eu cursava as séries iniciais.

Quanto ao quadro docente, as turmas de jardim à quarta-série contam com professores unidocentes; as demais séries, com um professor para 
cada área de ensino. Há uma diretora e duas vice-diretoras. Também há uma coordenadora para cada turno. $\mathrm{O}$ único homem no quadro funcional da escola, no turno da tarde, é o jovem porteiro.

Transcrevo aqui algumas anotações sobre o primeiro encontro com a coordenadora e a vice-diretora do turno da tarde, de como as expectativas recíprocas não se corresponderam imediatamente, ainda que meu ingresso na escola tenha sido bastante tranqüilo:

Fui à escola. Fui recebida pela vice-diretora do turno da tarde e pela coordenadora do turno. Expliquei-lhes o projeto. Elas ouviram-me e consentiram que eu realizasse o trabalho na escola, com as crianças. As expectativas delas em relação ao meu trabalho, como professora de teatro, pareciam ser outras. A vice-diretora logo comentou comigo, assim que cheguei, que se eu fosse fazer um trabalho a longo prazo, elas gostariam de uma 'pecinha' para as apresentações de Natal. Depreendo desta fala que elas pensaram que eu formaria um grupo de teatro com as crianças, daria aulas, montaria peças. A imagem do teatro na escola costuma ser esta: uma visão utilitarista, o 'teatrinho' que as crianças fazem para mostrar aos pais e colegas em datas / comemorações cívicas.

Durante alguns minutos de um recreio, expus minhas intenções de trabalho também às professoras, solicitando que indicassem um aluno por turma para participar do grupo com o qual realizaria as atividades de coleta de dados. Formaria um grupo misto de alunos/as, com o intuito de realizar as atividades de coleta. Seriam duas crianças por turma, um menino e uma menina, sendo uma das crianças indicada pela professora da turma e outra escolhida por sorteio, aleatoriamente. Por idéia da coordenadora, as professoras indicaram as meninas; eu sorteei, através das listas de chamada, os meninos. Mesmo assim, submeti os nomes às respectivas professoras. Alguns deles foram "vetados", pois, segundo elas, "iriam se prejudicar faltando às aulas". As professoras indicaram-me outros meninos.

O grupo, então, foi composto por 18 alunos, sendo 9 meninas e 9 meninos, com idades entre 5 a 11 anos; os alunos que freqüentam a escola em questão pertencem, eminentemente, à classe média. No segundo dia em que estive na escola, mais ou menos um mês antes da data prevista para apresentação do espetáculo teatral, conversei com as professoras no horário do recreio e solicitei 15 minutos para me apresentar às crianças e explicarlhes o projeto: o que eu pretendia fazer, saber se estavam interessados em participar, informá-las dos objetivos do projeto, esclarecer as dúvidas que possivelmente surgiriam.

Assim, após o término do recreio, esperei pelos alunos na sala que ficava 
no andar debaixo da sala dos professores. Em alguns minutos, ali estavam.

As crianças vão chegando, em duplas (um menino e uma menina). Olham-me desconfiados. Tento descontrair, digo oi, convidoos a sentar no chão comigo, em roda. Esperamos os que faltam chegar. Eles me perguntam o que estamos fazendo ali. Conversamos sobre coisas banais enquanto os outros não chegam. Todos, aparentemente, se conhecem, a escola é pequena. (...) Usam uniformes: calças pretas, moletons e blusões decote $v$ vermelhos, camisetas brancas, alguns casacos de abrigo. Logo percebo: foram escolhidos a dedo pelas professoras! São ativos, falantes, agitados. Fazem perguntas, estão curiosos. Conversamos, proponho uma apresentação em roda, em que cada um fale de si e do que gosta de fazer. Dois meninos da quarta-série mostram-se irrequietos: estão "perdendo" a aula de Educação Física! Nesse momento, reproduzo parte de minhas anotações sobre essa conversa, na qual as crianças falam de suas preferências:

As idades variam dos 6 aos 11 anos. Dentre suas preferências estão: jogar vôlei, espirobol, ler, estudar, nadar, assistir teatro (as meninas), jogar no computador, brincar de carrinho, jogar futebol (os meninos). Percebe-se que são crianças ativas, gostam de atividades desportivas, de movi- mento. São também falantes $e$ comunicativas.

Durante esse primeiro encontro, além de apresentar-nos, de explicar e esclarecer dúvidas acerca das atividades que desenvolveremos juntos, entrego-lhes um Termo de Consentimento Informado, documento esse que deve ser lido e assinado pelos responsáveis de cada criança, autorizando-me a realizar o trabalho de pesquisa e a utilizar os dados coletados nesta proposta de dissertação. Alguns pais e mães telefonaram-me a fim de obter alguns esclarecimentos depois de receberem o termo. Todos consentiram com a participação de seus filhos nas atividades que propunha.

No geral, as crianças pareceram empolgadas com a idéia de realizarem atividades diferentes das cotidianas, principalmente com os jogos e as entrevistas; ficaram muito excitados ao saber que suas falas seriam gravadas. Prometi-lhes que escutaríamos juntos, depois, aquilo que fosse gravado.

Naquele momento travávamos uma espécie de pacto, no qual eu me comprometia a oferecer-lhes alguns momentos lúdicos e prazerosos e eles comprometiam-se a colaborar prontamente comigo, desde que lhes fosse dada a oportunidade de, juntos, definirmos como efetuar praticamente o que eu propunha. E esse foi o início da construção de uma relação efêmera e produtiva, em que o estar junto rendeu, além de muitas dúvidas, risos, gritos, cochichos, pensares e viveres, um riquíssimo material de trabalho. 
Material palpável e material intangível, pois além dos registros, gravações, anotações, fotos, desenhos, há a experiência juntos. Ou seja, aquele entre nós que me constituiu e constitui-as, que fez de nós algo único e efêmero, naquela conformação espaço-temporal que dividimos, que juntos construímos e pela qual passaram afetos, dissabores, sons, rancores, odores, toques, sensações, expressões, enfim, tudo aquilo que não cabe no espaço do papel e que, por mais esforço descritivo que se faça, sempre estará indisponível a uma representação fidedigna. Ou seja; estará muito próximo daquilo a que tenho referido-me como essencialmente teatral: o inenarrável estar junto.

\section{BRINCANDO E INVENTANDO COM CORPOS VIVOS - JOGOS TEATRAIS}

Dia 3, Bento Gonçalves, 19 de setembro de 2003

Este encontro, no dia após a ida ao teatro, foi muito produtivo. Conversamos longamente sobre a peça, sobre outras peças que assistiram, sobre suas preferências, entrevistaram-me, interessados por minha história com o teatro, contaram-me suas histórias com o teatro. Após esta conversa, propus que fizéssemos três jogos teatrais: estátua em duplas, jogo do quadro/ fotografia sobre a peça ejogo Quem eu sou? livre. Muitas relações, significados e sentidos conferidos pelos alunos ao (e através do) espetáculo que assistiram no dia anterior surgiram durante os jogos, com seus gestos, ações, movimentos e falas. Corpos (re)produzindo e (re)criando a experiência do dia anterior, com o artefato teatral e sua linguagem peculiar. Corpos vivos brincando e inventando.

A linguagem teatral ${ }^{5}$ (com todas as implicações que advêm do uso desse termo) pode ser pensada como uma forma de jogo inexoravelmente ligada

\footnotetext{
4 Talvez possamos pensar no teatro enquanto o encontro de várias linguagens em um mesmo artefato, que seria o espetáculo cênico. Seriam elas:

-Linguagem visual ou plástica (cenários, figurinos, maquiagem, iluminação, elementos cênicos, etc.);

·Linguagem sonora e musical (vozes, entonações, ruídos, sons, músicas, trilhas sonoras, etc.); -Linguagem cinestésica ou dos movimentos, ações e gestos (ritmos, amplitude, tamanho, força, etc.);

-Linguagem dramática (o texto dramático, as falas ou as indicações de ações, a fábula, a narrativa, a história contada, etc.)

É importante salientar que para que ocorra o evento teatral, necessita-se, minimamente, de um ator que represente algo com alguma intenção estética diante de um espectador. A presença física e a troca, a comunhão efêmera entre um ator e um espectador, estas são as únicas características intrínsecas daquilo que chamamos linguagem teatral.
} 
à espécie humana. Segundo as características que Huizinga (2000) levanta como sendo próprias das atividades lúdicas, o teatro apresenta-se como uma modalidade de jogo por excelência.

Conforme esse autor, o jogo não é "vida corrente", é um intervalo na vida cotidiana e prosaica; contudo, é parte integrante de uma suposta "vida real" e utiliza-se de elementos e influências desta para sua posterior negação e reorganização no universo próprio do jogo. Tem sempre uma finalidade autônoma e se realiza tendo em vista uma satisfação que consiste no próprio ato de jogar, sendo uma atividade livre e voluntária, mesmo que siga regras internas rígidas, as quais devem ser aceitas e conhecidas por todos os jogadores para que ele suceda com êxito pleno. O jogo só pode existir em uma limitação definida de espaço e tempo: ele cria um espaço e um tempo próprios e durante esse espaço-tempo tudo é movimento, mudança, associação e separação; entretanto, o jogo cria ordem e é ordem, pois dentro de seus domínios a ordem deve ser específica e absoluta.

Após essa longa listagem de características abordadas por Huizinga (2000) como sendo necessárias a uma atividade lúdica ou jogo, posso inferir que há uma forte e marcada analogia entre as práticas teatrais e o jogo ou as atividades lúdicas. Tal como no jogo, no teatro busca-se uma espécie de evasão da vida prosaica na qual se constrói uma nova situação galgada em elementos retirados do contexto cultural e de seus sujeitos, reorganizados de forma estético-poética; a efemeridade e a limitação espacial do teatro são idênticas as do jogo (e absolutamente necessárias à existência de ambos); as regras do jogo são homólogas às convenções estéticas e éticas que seguimos na elaboração e reconhecimento de uma linguagem teatral (produtores e receptores devem conhecer e respeitar as mesmas regras no teatro). Assim sendo, mesmo que sejam atividades exteriores à vida cotidiana e habitual, tanto o teatro como o jogo são capazes de absorver os participantes de uma maneira intensa, criando uma tensão que "transportaria" os jogadores a um espaço-tempo diferenciado, extra-cotidiano.

No espaço-tempo não-cotidiano do jogo desenvolvem-se sentimentos "genuínos", como a sensação que experimentam os jogadores de estar "separadamente juntos" (HUIZINGA, 2000), em uma situação excepcional, partilhando algo importante. Logo, penso que no caso específico do teatro também aquilo que denomino neste trabalho de "comunhão teatral", ou o estar junto que vivenciam atores e espectadores, atores e atores e atores e personagens, possa ser significado por seus participantes enquanto algo que os arrebata e provoca sensações semelhantes ao envolvimento em um jogo coletivo. Portanto, o público deve ser seduzido e convencido a aceitar o jogo proposto pelos atores em cena e pela estética da encenação e seus elemen- 
tos, e a partir daí compartilhar das regras e (des)prazeres possíveis.

Após essas considerações iniciais que tiveram o intuito de contextualizar a analogia possível entre a linguagem teatral e o jogo, julgo ser pertinente ressaltar que a prática de jogos dramáticos e teatrais é amplamente utilizada tanto na formação de atores como na de platéias, bem como enquanto estímulo para a iniciação de crianças e adultos com a linguagem teatral e algumas de suas especificidades técnicas, formais e estéticas. Diversos autores, professores, diretores, atores de teóricos formularam suas metodologias da abordagem teatral através de jogos.

Trazendo agora para este espaço a justificativa do uso de jogos teatrais como uma das metodologias de coleta de dados junto às crianças espectadoras, posso dizer que desde o início da elaboração do trabalho minhas idéias encaminhavam-se no sentido de não somente ouvir as falas das crianças, ou seja, não me ater somente às informações que poderia obter através da linguagem verbal ou escrita. Ora, se o teatro apresenta-se marcadamente ligado a diversas linguagens, entre elas e talvez com mais força, pela linguagem dos movimentos e gestos dos atores em cena, por que não possibilitar às crianças que se expressem e expressem aquilo que sentem e pensam sobre a linguagem teatral através de seus corpos, da tonicidade e ritmo de seus movimentos, da plasticidade de seus gestos? Além disso, sendo eu uma professoratriz, parecia-me óbvio que abordasse aquelas crianças e tentasse construir uma relação com elas através da linguagem com a qual estou familiarizada e que, enfim, era/é o objeto central de minhas vontades de pesquisa.

Dessa forma, ofertei às crianças, desde nosso primeiro encontro, a possibilidade de realizarmos uma série de jogos teatrais, inspirados principalmente no sistema de Spolin (1987), que, segundo Desgranges, "está calcado em jogos de improvisação e tem o intuito de estimular o participante a construir o próprio conhecimento acerca da linguagem tetral, em um método em que o aluno, junto com o grupo, aprende fazendo, experimentando, e pensando criticamente acerca daquilo que foi realizado"(DESGRANGES, s/d, p. 5). De sua parte, as crianças acolheram a proposta e mostraram-se sempre muito entusiasmadas na realização das atividades que envolviam jogos teatrais e atividades lúdicas de caráter corporal e cinestésico.

No primeiro encontro, jogamos jogos de atenção, disponibilidade, confiança, ritmo, desinibição e respeito pelo corpo do colega, sempre pensando na relação palco-platéia, sendo que enquanto um grupo realizava o jogo, o outro observava; posteriormente, comentava-se a percepção e as impressões dos jogadores e observadores. Jogos de mimese corpórea também foram realizados, sempre encaminhando o foco na direção de meu objetivo central, que era o de obter dados que indicassem como aconte- 
cem as experiências das crianças com a linguagem teatral; tínhamos como temática o próprio teatro.

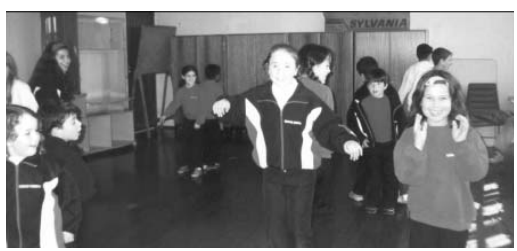

Figura 1 - Encontro 1 - Jogo das partes do corpo grudadas com deslocamento: jogo de atenção, confiança e disponibilidade.

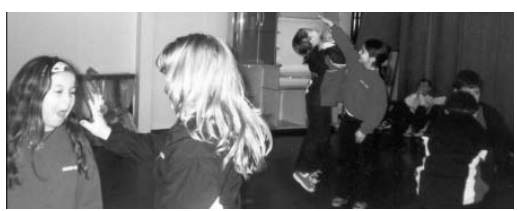

Figura 2 - Encontro 1 - Hipnose em duplas: jogo de concentração, corporeidade, confiança, ritmo.

Assim, não tive a intenção, com o uso dos jogos teatrais, de realizar algo que se assemelhasse aos que Desgranges (2003) nomeia de "animação teatral", ou seja, atividades com a finalidade de otimizar a recepção do espetáculo por parte dos espectadores. Simplesmente tentei possibilitar às crianças que expressassem seus sentires e construíssem significados acerca do teatro através da linguagem corporal, propiciada então pelos jogos.

Durante o Encontro 3, que sucedeu a assistência ao espetáculo teatral A Terrivel Viseira do Dr. Chip, propus vários jogos de mimese corpórea de caráter livre, em grupos, nos quais as crianças poderiam ou não reproduzir cenas, situações e personagens do espetáculo assistido. Diversas relações que as crianças construíram com o espetáculo em questão surgiram nesses jogos, bem como algumas concepções advindas de seu repertório cultural anterior também se fizeram presentes.

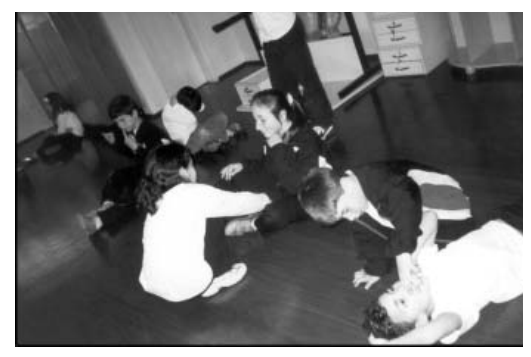

Figura 3 - Encontro 3 - Jogo da estátua em duplas, livre: os escultores montam suas estátuas.

\section{DESENHANDO E REPRESEN- TANDO OTEATRO-REGISTROS GRÁFICOS}

Dia 4, Bento Gonçalves, 22 de setembro de 2003

Neste dia, programei-me para que as crianças realizassem uma produção gráfica (desenho, pintura, colagem) acerca de suas experiências ou expectativas com o teatro. Após o horário do recreio, encontramo-nos todos no refeitório da escola, que conta com mesas coletivas amplas, brancas, com bancos acoplados. Quando disse a eles que naquele 
encontro iríamos desenhar, não gostaram muito da idéia. Queriam fazer outras atividades, como jogos e brincadeiras, com movimento e ação. Mesmo assim, acataram minha solicitação e dividiram-se nas duas mesas, com lápis de cor e material escolar variado. Propus que fizessem um desenho 'sobre teatro'. Poderia ser sobre a peça que haviam assistido, sobre outro espetáculo que tivessem visto, ou também sobre como gostariam que fosse uma peça, inventada por eles. Os desenhos foram os mais variados: do espetáculo do dia anterior, de outros 'teatros' a que haviam assistido ou dos quais tinham participado, sobre temáticas de suas preferências etc. Durante todo tempo conversamos bastante, crianças narravam a mim seus desenhos. Barulho e agitação. Alguns meninos queriam ir à aula de Educação Física. Alguma insegurança em relação a suas habilidades em desenhar, reproduzir cenas através do desenho. Tentei aclamá-los e incentivá-los. Ao acabarem suas produções, voltaram às respectivas salas de aula. Pois bem: as crianças desenharam o teatro. Houve algumas inseguranças em relação às suas capacidades de reproduzir graficamente da forma (as formas) almejada(s), que tentei amenizar incentivando-as, dizendo-lhes das possibilidades únicas de cada um expressar-se também através do desenho.
Durante a meia tarde barulhenta no limpo e branco refeitório da escola, contaram-me um pouco daquilo que desenhavam: histórias de amor novelescas, causos engraçados, de bichos, de teatros a que haviam assistido no passado e que (re)construíam agora na memória, de carros e motos que pareciam saídos de filmes hollywoodianos, dos personagens e elementos do espetáculo assistido no dia anterior, de histórias vistas e ouvidas, de outras inventadas, "o teatro que gostariam de ver".

Pillar (1996a) argumenta que “entende-se por desenho o trabalho gráfico da criança que não é resultado de cópia, mas da construção e da interpretação do objeto pelo sujeito" (PILLAR, 1996a, p. 33). Pensando em sentido homólogo ao dessa autora, escolho como uma das estratégias para a construção (junto às crianças) de dados a serem analisados a proposta de desenharem aquilo que pensam, lembram e sentem em relação ao teatro. Fiz isso de forma a possibilitar certa liberdade de escolha às crianças, procedendo de forma idêntica à que fiz com os jogos teatrais: propus-lhes que desenhassem qualquer coisa que lhes aprouvesse e que tivesse alguma ligação com o teatro, de forma a incitar que construíssem alguma relação com suas experiências com a linguagem teatral.

Quanto à qualidade dos dados representados por desenhos, registros gráficos das impressões e experiências de referido grupo de crianças com o teatro infantil, posso perceber, além da 
presença das relações com o teatral, diversas e diferenciadas mediações que compõem o repertório anterior dessas crianças enquanto espectadoras e sujeitos atravessados e constituídos através de determinada cultura. Então, pressuponho que "o olhar de cada um está impregnado com experiências anteriores, associações, lembranças, fantasias, interpretações, etc" e, portanto, penso que nos desenhos das crianças, em seus registros gráficos, “o que se vê não é o dado real, mas aquilo que se consegue captar e interpretar acerca do visto, o que nos é significativo.”(PILLAR, 1996, p. 36).

Assim sendo, considero esses artefatos que são os desenhos como importantes registros das experiências infantis com o teatro, ou seja, das experiências de construção de sentidos em relação à linguagem teatral que também se produziu no momento mesmo da elaboração desses desenhos, também eles "técnicas de si" que possibilitaram, de alguma forma, a constituição dos seus autores e de suas identidades de crianças espectadoras. Considero, assim, tanto os desenhos quanto as narrativas das crianças sobre eles, potenciais materiais a serem analisados e refletidos. Há necessidade de problematizar não somente a análise dos desenhos, mas o contexto em que foram produzidos, os esforços de seus produtores e as narrativas infantis sobre eles, ou seja, os sentidos que as crianças conferem àquilo que representaram graficamente.

Saliento, no entanto, que os mo- dos de olhar tais desenhos que busco desenvolver aqui não se aliam a teorias desenvolvimentistas e/ou cognitivistas, nem mesmo intento procurar qualquer reprodução realista nos traços das crianças. Pretendo, sim, percebê-los como " ( . . .) documentos históricos aos quais podemos recorrer ao necessitarmos saber mais e melhor acerca de seu mundo vivido, imaginado, construído, numa atitude investigativa que procure contemplar a necessidade de conhecer parte da História e de suas histórias segundo seus próprios olhares"'(GOBBI, 2002, p. 73).

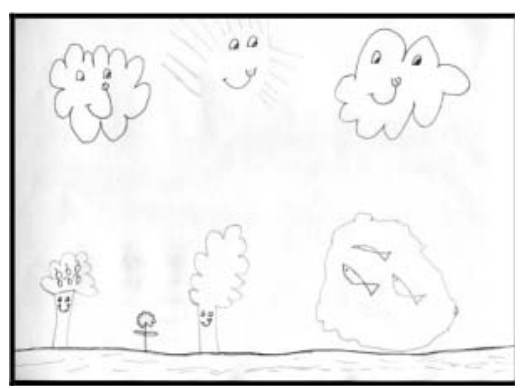

Figura 4 - Desenho de Mariana, 5 anos.

O desenho acima nos traz um claro exemplo de como pode acontecer a ressiginificação e a construção de sentidos a partir das práticas do desenhar e narrar a produção gráfica em contextos e situações determinados.

Mariana, uma esperta menina de 5 anos, aluna do Jardim B, desenhava compenetrada as formas que comumente aparecem nos desenhos das crianças dessa idade: um sol com nuvens arredondadas, uma flor, duas árvores, um lago com peixes colori- 
dos. Aproximo-me dela e pergunto:

- Mariana, este é o teatro que tu imaginou?

Surpreendida pela minha pergunta, responde prontamente:

- E!

- E onde estão os personagens? Insisto.

- Aqui ó, são os atores vestidos Responde ela desenhando rapidamente bocas e olhos em nuvens, sol e árvores. - O sol fala com as nuvens que falam com as árvores, são os atores vestidos...

- Ah, tá.... é que eu não tinha entendido...

Resigno-me, então, a não desafiar mais a imaginação da Mariana. Desenhava pelo prazer de desenhar e, interpelada pela "outra", adulta e professora que era eu naquele momento, astutamente ressignificou aquilo que desenhava para agradar a mim e a meus anseios de pesquisadora que queria saber sobre o teatro e as crianças.

\section{NARRANDO(SE) E CONSTRUINDO(SE) ESPECTA- DOR/A - ENTREVISTAS E CON- VERSAS}

Dia 5, Bento Gonçalves, 23 de setembro de 2003

Este foi o último dia em que estivemos juntos. Entrevistei-os em grupos: dividi as crianças pelas séries que freqüentavam. Os grupos das quartas, terceiras e se- gundas séries com quatro crianças cada, o último grupo contou com seis alunos/as: quatro da primeira série e dois do Jardim B. Cada entrevista durou, em média, 1 hora. A entrevista como Grupo 1, das quartas séries, transcorreu tranqüilamente. Vi e Em estavam um pouco retraídos, ou não muito atraídos pelas perguntas. No entanto, todas as questões foram respondidas e comentadas. No Grupo 2, formado pelos/ as alunos/ as das terceiras séries, a entrevista foi uma atividade muito producente: eram todos falantes e tinham muita vontade de participar, respondendo às perguntas e elaborando outras, interagindo entre si, como em uma 'conversa orientada' ou 'temática', concordando e discordando uns dos outros, em um exercício de livre expressão. Já com o Grupo 3 (segundas séries), foi bastante dificil realizar a entrevista: todos muito agitados e dispersos, eu também já estava cansada e impaciente por ter feito outras duas entrevistas, sem pausa. Durante muitos momentos implicaram e brigaram uns com os outros, dispersando-se. Fomos interrompidos pelo recreio. Continuamos por um curto tempo após o término do recreio. As crianças do Grupo 4 (primeiras séries e jar$\operatorname{dim} B$ ) responderam às perguntas com muita desenvoltura, principalmente no concer-nente à tele- 
visão e aos desenhos animados. Falavam todos ao mesmo tempo, tumultuados e alegres, mas conseguimos nos organizar de forma a todos ouvirmos e falarmos.

Ao optar por realizar entrevistas semi-dirigidas ${ }^{4}$ com as crianças com as quem estive junto, inclui dentro da estratégia de pesquisa que me propus a desenvolver um importante mecanismo de constituição e (re)invenção de si, que é a narrativa da experiência. Em uma relação polifônica (entre as várias vozes das crianças que participaram de cada grupo entrevistado e os diversos discursos que teceram relações intertextuais em seus enunciados) e dialógica (havia dois "tipos" de vozes diferentes envolvidas: a minha, de professoratriz; "outra", adulta e pesquisadora; e as das crianças, sujeitos-personagens da pesquisa), que caracteriza o gênero entrevista, demos continuidade à construção (já iniciada nas outras atividades que cronologicamente a antecederam) de nossas "identidades narrativas".

Acerca desse conceito, Carvalho afirma: "A noção de identidade narrativa supõe um processo estrutural formador do que Ricoeur denomina ipseidade - compreendida como a identidade de um si mesmo relacional e, portanto, marcado pela abertura de um ser afetado pelo mundo, em contraste com uma identidade fixa do mesmo" (CARVALHO, 2003, p. 6). Sobre as questões relativas à polifonia percebida nas "narrativas do eu" (entre as quais encontram-se os relatos provenientes de entrevistas, como as que realizei com as crianças), essa mesma autora argumenta: "Nesse jogo polifônico, o sentido não está nunca aprisionado numa intenção ou significado prévio, mas é efeito imprevisível de um encontro de alteridades, portanto somente acontece numa situação de comunicação e está fadado às vicissitudes da recriação permanente" (id ibid, p.10).

Assim sendo, reitero que relações de força atravessaram e perpassaram tanto as crianças como eu, bem como o pacto que, de forma efêmera, construímos juntos e também nos constituiu em sua produtividade, pois, "o relato autobiográfico não representa o sujeito, mas o produz. Daí a natureza de auto-invenção do relato autobiográfico" (id ibid, p.11). Em consonância com essas proposições, ainda podemos pensar que "Essa auto-invenção, por sua vez, traz consigo a invenção do Outro, das relações de alteridade e, portanto, da identidade narrativa de um campo intersubjetivo

${ }^{4}$ Segundo Orozco (2000), uma entrevista semi-dirigida caracteriza-se por ter alguns núcleos temáticos de assuntos a serem discutidos elaborados anteriormente pelo pesquisador, o que não significa que as perguntas a serem feitas serão estanques e definidas. Há mobilidade nas perguntas e respostas, contudo estas serão conduzidas pelo pesquisador dentro de eixos temáticos pré-estabelecidos.

Olhar de professor, Ponta Grossa, 7(1): 43-66, 2004. 
e cultural em questão. É nesse sentido que a auto-invenção dos sujeitos é simultaneamente posicionada num campo social e demarcadora desse mesmo campo" (id ibid, p. 11).

Portanto, todo enunciado é modulado pela presença do outro, dos destinatários ou interlocutores. Não posso perder isso de vista ao manusear o material fruto de minhas experiências empíricas com as crianças, inclusive as transcrições de conversas e entrevistas. Algumas questões propostas por James Clifford e reelaboradas por Arfuch (2002) devem ser levadas em conta: "O que fazer com a palavra do outro? Como transcrever o registrado? Que signos respeitar e recolocar, como analisá-la e expô-la, a sua vez, à leitura pública (acadêmica, editorial, midiática)?" (ARFUCH, 2002, p. 192).

Abordo neste espaço um excerto de conversa com o grupo de crianças, no qual elas próprias levantam aspectos da relação dialógica que estabelecemos, da existência de um gravador e outros mecanismos naquele espaço-tempo em que estivemos juntos, bem como se evidenciam algumas relações de força entre nós estabelecidas, a forma como conduzo e medeio nossas conversas sobre teatro de acordo com meus interesses de pesquisadora.

Juliana - Pessoal, ela tá gravando. Paula - É. Ela tá gravando.

Eu - Tudo bom com vocês?

Alguns - Tudo.

(Saio da sala para pegar água enquanto as outras crianças vão chegando, eles falam para o gravador, ameaçam desligar, etc, volto para sala, eles continuam às voltas com o gravador)

Eu - Qual é o problema que tá gravando? Vocês querem ouvir um pouquinho?

Juliana - Sim!!!!!

(Volto a fita e deixo que escutem. Quando todos chegam, sentamos no chão, em um círculo)

Andressa - Profe, quando é que a gente vai poder ver a gravação de ontem e do outro dia que o Marcelinho gravou?

Eu - Quando eu conseguir passar para a outra fita normal de vídeo eu trago pra vocês verem. Tem vídeo aqui na escola?

Juliana - Tem. Na biblioteca e na sala do Jardim.

Eu - Pessoal, tudo bem com vocês? Antes da gente iniciar as atividades, a gente vai fazer outros jogos hoje, diferentes dos do outro dia...

Andressa (interrompendo) Profe, tu vai perguntar alguma coisa do teatro?

Eu - Vou, é o que eu ia dizer, antes da gente começar trabalhar, eu queria que, um por vez, devagarinho, falasse o que quisesse: o que gostou, o que não gostou... Porque tem coisa que a gente não gosta, ninguém é obrigado a gostar de tudo, como é que foi ir até lá, voltar, se quiserem falar de outros teatros que já assistiram 
podem falar... O que vocês quiserem falar! Certo? [grifo meu]

Como havíamos assistido ao espetáculo teatral na tarde anterior, a menina Andressa em sua fala já antecipa e prevê que eu perguntaria algo sobre essa experiência; afinal, havia esclarecido a eles porque eu estava na escola e porque realizávamos aquelas atividades todas, qual era meu propósito com isso. Depois de algum tempo de conversa, paulatinamente inverteram-se as posições e então as crianças começaram a me entrevistar, perguntaram sobre minhas experiências teatrais, mostraram-se curiosas sobre a minha relação com o teatro. Esse deslocamento de nossas posições de pesquisadora e sujeitos de pesquisa me pareceu um profícuo momento de troca e de confiança que conseguimos estabelecer. Reproduzo aqui parte dessa "inversão de papéis", explícita na fala surpresa de Andressa: "Agora é a gente que tá te entrevistando!”.

Andressa - Profe, quando tu decidiu que queria fazer teatro?

Eu - Quando eu era bem pequena, assim do tamanho de vocês... (Continuam fazendo uma série de perguntas acerca de minha vida com o teatro)

Karina - Tu não teve vontade de trabalhar na TV?

Eu - Não, Karina, eu nunca tive vontade de fazer TV. Eu gosto mesmo é de fazer teatro.

Andressa - E tu já teve vontade de fazer outra coisa?
Paula - Quando tu começou a fazer teatro tu tinha certeza que tu ia ser professora de teatro e fazer teatro?

Eu-Olha, certeza, certeza eu não tinha, porque eu era muito pequena, mas eu sempre gostei muito de fazer teatro, e sempre fiz. A $i$ quando chegou na época de fazer vestibular... Vocês sabem o que é vestibular? É antes de entrar na faculdade, a gente faz uma prova.

Juliana - Um teste!

Andressa - Agora é a gente que tá te entrevistando!

Vicente - O primeiro teatro que tu fez tu não ficou assim, um pouco com vergonha?

Eu - Fiquei... Até hoje dá um medo antes de começar.

Seguindo as reflexões sobre as entrevistas, saliento que para Arfuch (1995), uma das intelectuais latinoamericanas que tem desenvolvido trabalhos acerca das entrevistas e narrativas autobiográficas como gêneros discursivos, a entrevista pode parecer uma simples conversação, contudo, tem seus limites bem claros, como o lugar ocupado por entrevistados e entrevistador e a temática estabelecida, em alguns casos. Essa mesma autora ressalta o caráter de narrativa que as entrevistas podem assumir, conferindo-lhes características como a fragmentação, a incerteza e a incompletude.

No mesmo sentido das colocações de Arfuch (1995), é Larrosa (1995) 
quem discorre acerca dos processos de narrar-se enquanto uma tecnologia da constituição de si: "o narrador é o que expressa, no sentido de exteriorizar, o rastro que aquilo que viu deixou em sua memória", sendo que "a recordação não é apenas a presença do passado", mas ela "implica a imaginação e a composição, implica um certo sentido do que somos, implica habilidade narrativa" (LARROSA, 1995, p. 68). Compartilho com esse autor a idéia de que: "é contando histórias, nossas próprias histórias, o que nos acontece e o sentido que damos ao que nos acontece, que nos damos a nós próprios uma identidade no tempo" (Id ibid, p. 69). Logo, posso inferir que as conversações e entrevistas realizadas com as crianças foram exercícios de narração e auto-narração que constituíram também suas identidades de espectadores de teatro (além de me constituírem professoratriz de teatro). Durante o lembrar, narrar e (re)inventar suas experiências com o teatro, construíamos sentidos e significados que eram conferidos à relação das crianças com a linguagem teatral, articulando-as às suas diversas experiências como espectadores híbridos na contemporaneidade. Saliento que durante as atividades com os jogos teatrais e os desenhos também construímos narrativas através de duas linguagens que não a verbal: a corporal e a gráfica.

Ainda que haja uma série de mediações que interpolam o espaço en- tre as experiências e os significados que conferimos a elas através de nossos discursos e narrativas, esses significados não são prévios ou antecedem o momento mesmo de sua enunciação. Mesmo que os discursos e as narrativas possam ser considerados polifônicos e portadores de diversas vozes, de uma intertextualidade inerente, ainda que cada uma das crianças estivesse implicada em uma relação eminentemente dialógica (comigo e também com seus colegas, já que as entrevistas e conversas realizaram-se em grupos), elas produziram sentidos e produziram-se enquanto sujeitos em relação ao teatro, ou seja, constituíramse espectadoras. Tais sentidos e posicionalidades assumidas foram sempre permeados pelas múltiplas mediações que atuaram e atuam na constituição desse grupo de crianças em relação com a linguagem teatral.

\section{BREVES CONSIDERAÇÕES A TÍTULODE FINALIZAÇÃO}

A título de encerramento destes escritos, mas não das possibilidades investigativas que se apresentam, valho-me das palavras de Quinteiro a fim de justificar essa estratégia multimetodológica utilizada, ainda que pense que sua justificativa encontrase no fazer mesmo das práticas que propus às crianças e que elas gentilmente acolheram, hospedaram e reinventaram, construindo-se assim a si próprias. Para essa autora, "falta por 
parte dos estudos etnográficos, da pesquisa participante, do inventário dos artefatos, das produções culturais, das histórias de vida e das entrevistas biográficas propiciar um conjunto integrado de métodos e técnicas que possa subsidiar as pesquisas relativas à criança e à infância no campo educacional" (QUINTEIRO, 2002, p. 41). Apresentei, portanto, neste trabalho, a tentativa de concretizar empiricamente algo semelhante ao que se refere a autora acima citada.

A partir dos momentos vividos com as crianças, possuo agora, além das intangíveis e inenarráveis sensações e sentimentos, algum material palpável e visível em sua concretude. E é esse mesmo material que pretendo ampliar, fazendo com que seus sentidos e significados dilatem-se, exerçam-se, (re)vivam, através das análises e reflexões que farei acerca deles. Logo, “[...] a entrevista utilizada na investigação acadêmica [...] será um passo para ir 'mais adiante', até a elaboração de um produto outro [...]" (ARFUCH, 2002,p. 179) pelo pesquisador. Arfuch refere-se especificamente às entrevistas, mas posso ampliar essa referência à variabilidade de dados construídos através da estratégia multimetodológica de pesquisa empírica que aqui propus, através do uso de registros gráficos, jogos teatrais, conversações e entrevistas, inspirada nas etnografias pós-modernas. Meu trabatho de pesquisadora constitui-se, agora, em encontrar, criar, conferir significados e sentidos a esse material.

\section{REFERÊNCIAS}

ARFUCH, L. La entrevista, una invención dialógica. Barcelona: Paidos, 1995.

EI espacio biografico: dilemas de la subjetividad contemporanea. Buenos Aires: FCE de la Argentina, 2002.

CARVALHO, I. C. M. Biografia, identidade e narrativa: elementos para uma análise hermenêutica. Horizontes antropológicos, Porto Alegre, UFRGS, v. 9, n. 19, jul. 2003.

CLIFFORD, J. Sobre la autoridad etnográfica. The Predicament of Culture, Cambridge, Harvard University Press, p. 21-54, 1988.

DERRIDA, J. Torres de babel. Belo Horizonte: UFMG, 2002.

DESGRANGES, F. A pedagogia do espectador. São Paulo: HUCITEC, 2003 a.

O jogo teatral de Viola Spolin. (Texto digitado para fins didáticos), [s/d].

FISCHER, R. M. B. A análise do discurso: para além de palavras e coisas. Educação e Realidade, Porto Alegre, v. 20, n. 2, p. 18-37, jul./dez. 1995.

GEERTZ, C. Estar lá, escrever aqui. Diálogo, São Paulo, v. 22, n. 3, p. 58-63, 1989.

GOBBI, M. Desenho infantil e oralidade: instrumentos para pesquisas com crianças pequenas. In: FARIA, A. L. G. et al (Orgs.). Por uma cultura da infância: metodologias de pesquisa com crianças. Campinas: Autores Associados, 2002.

GOTTSCHALK, S. Postmodern sensibilities and ethnographic possibilities. In: BANKS, A.; BANKS, S. (Ed.). Fiction and social research: by ice or fire. London: Altamira Press, 1998. p. 205-233 
HUIZINGA, J. Homo ludens: o jogo como elemento da cultura. São Paulo: Perspectiva, 2000.

LARROSA, J. Tecnologias do eu e educação. In: SILVA, T. T. O sujeito da educação: estudos foucaultianos. Petrópolis: Vozes, 1995. p. 35-86.

OROZCO GÓMEZ, G. La investigación en comunicación desde la perspectiva cualitativa. La Plata, Ar: UNLaPlata, 2000.

PILLAR, A. D. Desenho e construção de conhecimento na criança. Porto Alegre: Artes Médicas, 1996.

Desenho e escrita como sistemas de representação. Porto Alegre: Artes Médicas, 1996a.

QUINTEIRO, J. Infância e educação no Brasil: um campo de estudos em construção. In: FARIA, A. L. G. et al (Orgs.). Por uma cultura da infância: metodologias de pesquisa com crianças. Campinas: Autores Associados, 2002.

SARMENTO, M. J. O estudo de caso etnográfico em educação. In: ZAGO, N. et al (Orgs.). Itinerários de pesquisa: perspectivas qualitativas em sociologia da educação. Rio de janeiro: DP\&A, 2003. p. $137-179$

SPOLIN, V. Improvisação para o teatro. São Paulo: Perspectiva, 1987.

VEIGA NETO, A. Cultura, culturas e educação. Revista Brasileira de Educação, n. 23 , p. 5-15, mai.-ago. 2003. 